\title{
Biological aspects of sharks caught off the Coast of Pernambuco, Northeast Brazil
}

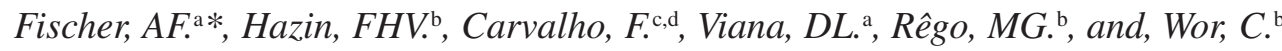

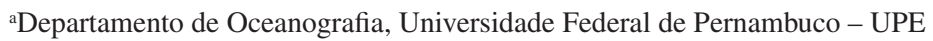 \\ Av. Arquitetura, s/n, CEP 50670-901, Cidade Universitária, Recife, PE, Brazil.

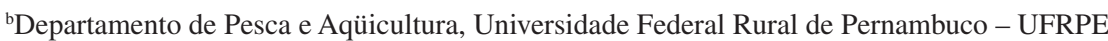 \\ Av. Dom Manoel de Medeiros, s/n, CEP 51171-900, Dois Irmãos, Recife, PE, Brazil \\ 'Department of Fisheries and Aquatic Sciences, University of Florida, \\ 7922 NW 71 ${ }^{\text {st }}$ St., Gainesville, FL 32653, USA \\ dFlorida Program for Shark Research, Florida Museum of Natural History, \\ University of Florida. Museum Road, Gainesville, F1 32611, USA \\ *e-mail:leccafischer@yahoo.com.br
}

Received June 12, 2008 - Accepted August 21, 2008 - Distributed November 30, 2009

(With 10 figures)

\begin{abstract}
One hundred seventeen specimens of sharks were caught along the coast of Pernambuco State, Northern Brazil, between May 2004 and May 2007, among which 86 were blacknose sharks, Carcharhinus acronotus, enabling a more detailed study of the species. Blacknose sharks were caught in the 2 study areas along the Boa Viagem/Piedade and Paiva beaches, accounting for the highest relative abundance among the species caught (73.5\% of total). Potentially dangerous sharks, tiger and bull sharks, were also caught in the same areas, whereas hammerhead and blacktip sharks were only captured off Boa Viagem/Piedade. Concerning the blacknose shark, the total length (TL) ranged from 39.0 to $180.0 \mathrm{~cm}$. Among the 38 females analysed, 32 were juveniles, 11 were maturing, 2 were pre-ovulatory and 21 were pregnant. Sexing was possible for 75 of the 83 embryos, 38 of which were males and 37 were females, with a sex proportion of 1:0.9 and total length ranging between 6.4 and $63.5 \mathrm{~cm}$. Ovarian fecundity ranged from 5 to 10 and uterine fecundity from 1 to 3, with an estimated gestational period of 9 months. Among the 48 males, 6 were juveniles and 42 were adults. Both males and females seem to reach sexual maturity at about $105.0 \mathrm{~cm}$ TL. Among the 86 stomachs analysed, only $22.1 \%$ had contents, with teleosts as the most frequent item.
\end{abstract}

Keywords: biology, abundance, sharks, Pernambuco.

\section{Aspectos da biologia dos tubarões capturados na Costa de Pernambuco, Brasil}

\section{Resumo}

Entre maio de 2004 e maio de 2007, foram capturados 117 exemplares de tubarões na costa de Pernambuco. Desses, 86 eram tubarões-flamengo, Carcharhinus acronotus, possibilitando um estudo mais detalhado da espécie. Esta espécie foi capturada nas duas áreas estudadas, nas praias de Boa Viagem/ Piedade e Paiva, apresentando a maior abundância relativa entre os tubarões capturados (73,5\% do número total). Tubarões potencialmente perigosos (tigre e cabeça-chata) foram também capturados nas duas áreas, enquanto os tubarões-martelo e galha-preta foram capturados apenas em frente à Boa Viagem/ Piedade. O comprimento total (CT) dos tubarões-flamengo variou de 39,0 a 180,0 cm CT. Das 38 fêmeas analisadas, 32 eram jovens, 11 em maturação, 2 pré-ovulatórias e 21 prenhes. Dos 83 embriões, foi possível a sexagem de 75, dos quais 38 eram machos e 37 fêmeas, com proporção sexual de 1:0,9, e CT entre 6,4 e 63,5 cm. A fecundidade ovariana variou entre 5 e 10 e a uterina entre 1 e 3, com período gestacional estimado em 9 meses. Dos 48 machos, 6 eram jovens e 42 adultos. Tanto machos quanto fêmeas parecem alcançar a maturação sexual em torno de 105,0 cm CT. Dos 86 estômagos de tubarões-flamengo analisados apenas 22,1\% apresentavam conteúdo, com teleósteos sendo o item mais frequente.

Palavras-chave: biologia, abundância, tubarões, Pernambuco. 


\section{Introduction}

Despite the intense recreational use of beaches in the Metropolitam Region of Recife (RMR) in the state of Pernambuco, northern Brazil, since the early 1950s, except for a few unconfirmed anecdotal reports of shark attacks, there were virtually no records of such incidents in the area until 1992. From June 1992 to September 2006, however, 47 attacks were recorded, including 17 fatalities (Hazin et al., 2008). These numbers had a considerable negative socioeconomic impact on the state of Pernambuco, resulting in a significant reduction in the number of tourists and compromising one of the most popular forms of leisure for the local population. To contextualise this, approximately 360 thousand people in the state either directly or indirectly depend upon tourism activities and $64 \%$ of the rooms made available by the hotel industry are located within the area of risk, between the Paiva and Pina Beaches (EMBRATUR, 2006).

On May 17, 2004, the State Government of Pernambuco instituted the Shark Incident Monitoring Committee, which began to develop research and monitoring activities, using the Research Vessel "Sinuelo", under the coordination of the Department of Fisheries and Aquaculture of the Universidade Federal Rural de Pernambuco. Fishing surveys using bottom longlines and drumlines were employed to catch sharks, aiming at broadening the knowledge about the sharks of Pernambuco coast, including information on migratory movements, seasonal fluctuation of abundance, reproductive biology, and feeding habits.

With the exception of the 3 species of sharks considered potentially dangerous to humans - the tiger shark (Galeocerdo cuvier), the bull shark (Carcharhinus leucas) and the blacktip shark (Carcharhinus limbatus) - all species caught alive at haulback of the fishing gear were released back to sea. Those found dead or with their survival clearly compromised (hooked internally), as well as the 3 shark species citied above, were landed for subsequent biological studies.

Knowledge on the biological characteristics of sharks along the beaches in the RMR, including the identification of the most abundant species, as well as ontogenic and physiological conditions, is fundamental to an adequate understanding of the causes and conditions that caused the shark attack outbreak in the State, since 1992. Without this understanding, the adoption of measures to reduce the incidence of attacks and the subsequent socioeconomic impacts become much more difficult. Furthermore, the elasmobranchs have peculiar biological features, such as late sexual maturity and low fecundity, which make them much more vulnerable to over-fishing (Bonfil, 1994). The generation of basic information on shark species present around the beaches of Recife, which are regularly targeted by artisanal fisheries, is, therefore, crucial to ensure the sustainability of their stocks. Thus, the objective of this study was to provide biological information of sharks caught along the beaches in the RMR, between May 2004 and May 2007, focusing on the blacknose shark, which represented the vast majority of the catches.

\section{Materials and Methods}

\subsection{Study area}

The Metropolitan Region of Recife ( $08^{\circ} 34^{\prime} \mathrm{S}$ and $34^{\circ} 52^{\prime} \mathrm{W}$ ) has a humid and tropical climate with two well-defined seasons: a rainy season from March to August and a dry season from September to February (Coutinho et al., 1998). The coastline is approximately $20 \mathrm{~km}$ long and includes the Paiva, Candeias, Piedade, Boa Viagem and Pina beaches, which have sea water temperatures ranging from about $24{ }^{\circ} \mathrm{C}$, during winter, to $30{ }^{\circ} \mathrm{C}$ during summer (Hazin et al., 2000). These 5 beaches are under the influence of the Barra de Jangada estuarine system formed by the Pirapama and Jaboatão rivers (Noriega et al., 2005), which together drain an area of approximately $1,000 \mathrm{~km}^{2}$ into the Atlantic Ocean (Carneiro and Coelho, 1960) (Figure 1).

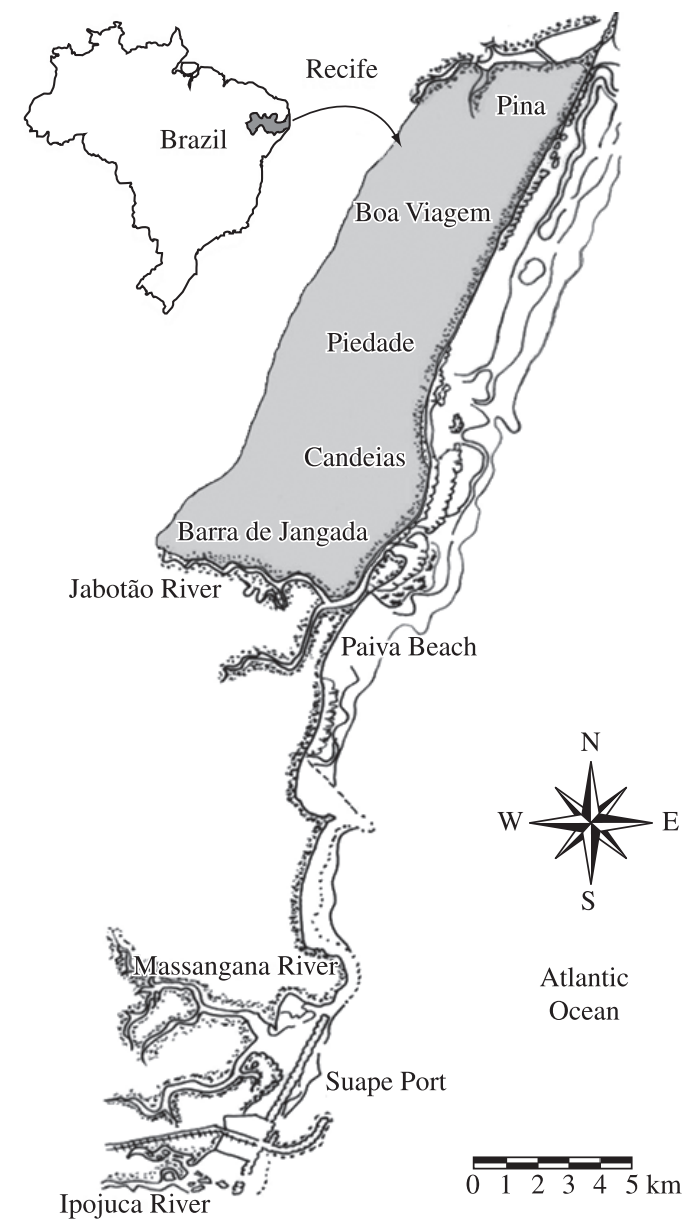

Figure 1. Stretch of coastline along the State of Pernambuco with indication of the area (in grey) situated between the Paiva and Pina beaches, in front of which the longline and drumline fishing operations were performed (Modified from Hazin et al., 2008). 


\subsection{Sample collection}

One hundred and five fishing surveys were carried out between May 2004 and May 2007. A total of 1,438 fishing sets were performed using bottom longline and drumlines. The longline consisted of a main multifilament polyamide line, $8 \mathrm{~mm}$ in diameter and $4 \mathrm{~km}$ in length, subdivided into 4 segments, each delimited by 2 buoys and containing 25 hooks, for a total of 100 hooks. Two longlines were used at each deployment: 1 in front of the Pina/Piedade stretch of beach and another in front of Paiva Beach, totalling 200 hooks. Secondary lines were also made of polyamide line, $8 \mathrm{~mm}$ in diameter and $8 \mathrm{~m}$ in length, culminating in 2 one-meter long steel gangions connected to a swivel and a hook at the end. The drumlines were deployed in pairs and had a structure similar to those used in the longline. Twenty drumlines were used at each deployment, with 2 hooks each: 10 in front of the Pina/Piedade stretch of beach and 10 in front of Paiva beach, totalling 40 hooks.

\subsection{Biology}

All sharks caught in the botton longlines and drumlines were identified and sexed according to Compagno (1984). Measurements of total length (TL), pre-caudal length (PCL), fork length (FL), and interdorsal length (IDL) were recorded in cm. Total weight (TW) and eviscerated weight $(\mathrm{EW})$ were obtained before and after the dissection process, respectively.

For the study of the reproductive biology, the specimens were dissected and the reproductive organs from males (testes and epididymis) and females (ovaries and oviduct glands) were collected. In females, the number of vitellogenic follicles was counted and the follicle with the largest diameter was measured. After being measured, the uteri were sectioned longitudinally for the examination of their contents. Eggs and embryos were counted and preserved in $70 \%$ ethanol solution. Embryos were measured (TL), weighed (TW) and sexed for the calculation of sex ratio. Length and calcification stage of claspers, width of epididymis, and the presence of seminal fluid in the ampullae of the ductus deferens were recorded from males. The method used by Hazin et al. (2000) and Pratt (1979) was used for the definition of the maturation stages for males and females.

For the study of feeding habits, stomachs were collected from all the specimens sampled and sectioned from the esophagus until the anterior portion of intestine. The samples were stored in plastic bags and preserved in $70 \%$ ethanol solution. Stomachs were later opened and the contents collected, being then filtered in 1-mm mesh sieves, identifying the items to the lowest possible taxonomic group. The percentage in number and frequency of occurrence of all items was assessed following procedures described by Vaske and Rincón (1998). Due to the much higher number of blacknose sharks analysed, the study of its reproductive biology and stomach contents was performed in a much more detailed manner in comparison to the remaining species.

The Catch Per Unit of Effort (CPUE) was used as an index of relative abundance, based on the number of individuals caught per 1,000 hooks. Longline soak time at Boa Viagem/Piedade and Paiva, and fishing effort over the months and between the 2 study areas were approximately consistent throughout the sampling period. Thus, there was no need for standardisation of the CPUE throughout the sampling period.

For the blacknose shark, linear regressions between TL and different lengths and weights measured were calculated. Equations were estimated separately for males and females and later compared using analysis of covariance (ANCOVA). For this analysis, values referring to the weight of individuals were transformed by the natural logarithm (nl).

\section{Results}

A total of 117 sharks were analysed: 86 blacknose sharks, Carcharhinus acronotus (38 females and 48 males), 20 tiger sharks, Galeocerdo cuvier (5 females and 14 males), 6 bull sharks, Carcharhinus leucas (4 females and 2 males), 3 blacktip sharks, Carcharhinus limbatus ( 2 females and 1 male), and 2 great hammer-

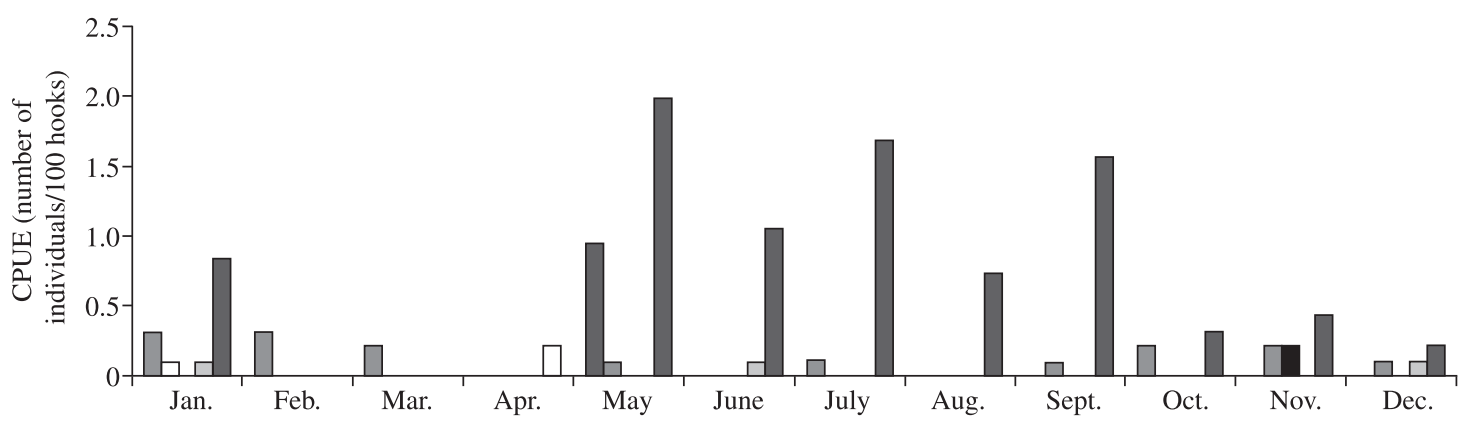

$$
\square \text { Tiger shark } \square \text { Blacktip shark } \square \text { Bull shark } \square \text { Blacknose shark } \quad \text { Hammerhead shark }
$$

Figure 2. Monthly catch per unit of effort (CPUE) of shark species captured by the Sinuelo research vessel along the coast of Pernambuco. 


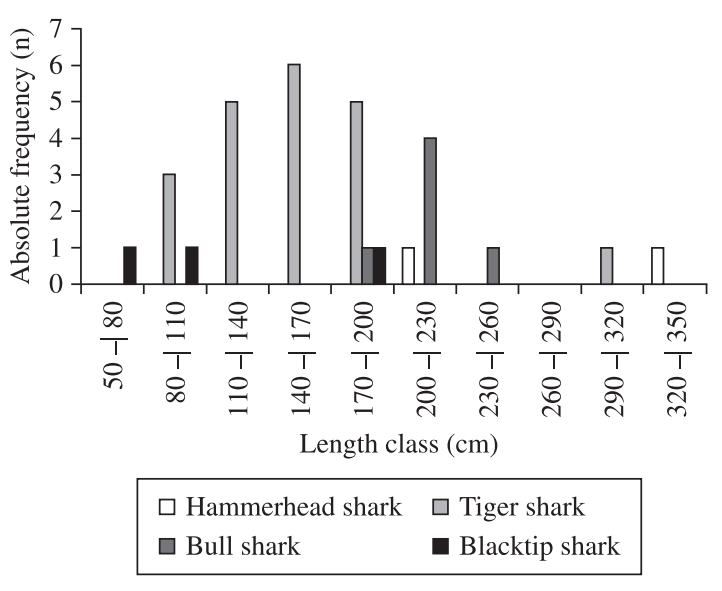

Figure 3. Frequency distribution of total length of sharks caught by the Sinuelo research vessel along the coast of Pernambuco.

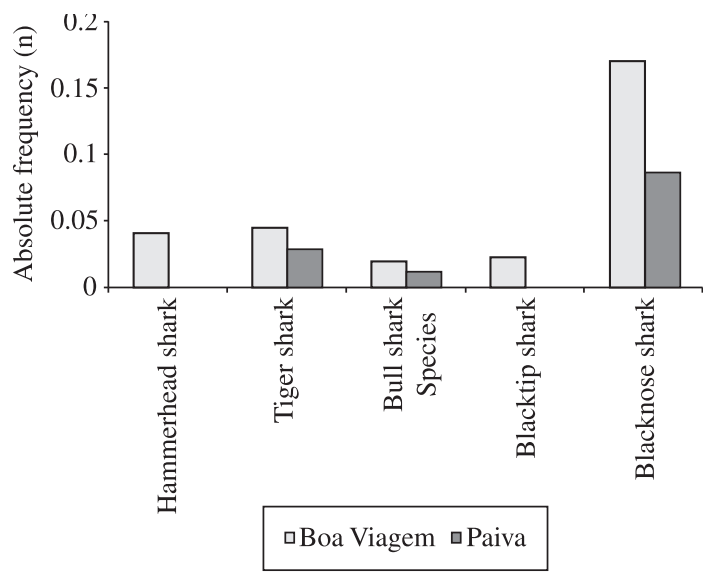

Figure 4. Catch per unit of effort (CPUE) by area (Boa Viagem and Paiva) of sharks captured by the Sinuelo research vessel along the coast of Pernambuco.

Table 1. Summary of linear regressions for the measurements of male and female blacknose sharks, F values for the comparison between slopes $(\beta)$ and intercepts $(\alpha)$ and the equations for the grouped data.

\begin{tabular}{|c|c|c|c|c|c|c|c|}
\hline Males - Equation & $\mathbf{r}^{2}$ & Females - Equation & $\mathbf{r}^{2}$ & $\alpha$ & $\beta$ & Both - Equation & $\mathbf{r}^{2}$ \\
\hline $\begin{array}{c}\mathrm{nl} \mathrm{TW}=0.0363 \mathrm{TL} \\
+4.8968\end{array}$ & 0.93 & $\begin{array}{c}\mathrm{nl} \mathrm{TW}=0.0378 \mathrm{TL} \\
+4.6886\end{array}$ & 0.73 & 0.83 & 0.84 & $\mathrm{nl} \mathrm{TW}=0.0371 \mathrm{TL}+4.7823$ & 0.77 \\
\hline $\begin{aligned} \mathrm{nl} \mathrm{EW} & =0.0363 \mathrm{TL} \\
& +4.7975\end{aligned}$ & 0.93 & $\begin{aligned} \mathrm{nl} \mathrm{EW} & =0.0364 \mathrm{TL} \\
& +4.6753\end{aligned}$ & 0.72 & 0.92 & 0.92 & $\mathrm{nl} \mathrm{EW}=0.0360 \mathrm{TL}+4.7848$ & 0.75 \\
\hline $\begin{aligned} \mathrm{FL} & =0.8084 \mathrm{TL} \\
& +0.072\end{aligned}$ & 0.89 & $\begin{aligned} \mathrm{FL} & =0.9358 \mathrm{TL} \\
& -10.871\end{aligned}$ & 0.93 & 0.51 & 0.51 & $\mathrm{FL}=0.9451 \mathrm{TL}-13.4853$ & 0.90 \\
\hline $\begin{array}{c}\mathrm{IDL}=0.2762 \mathrm{TL} \\
-2.9839\end{array}$ & 0.88 & $\begin{array}{l}\mathrm{IDL}=0.249 \mathrm{TL} \\
\quad+0.3383\end{array}$ & 0.77 & 0.01 & 0.01 & $\mathrm{IDL}=0.2578 \mathrm{TL}-0.8530$ & 0.80 \\
\hline $\begin{aligned} \mathrm{PCL} & =0.8202 \mathrm{TL} \\
& -6.477\end{aligned}$ & 0.63 & $\begin{aligned} \mathrm{PCL} & =0.7413 \mathrm{TL} \\
& +1.8\end{aligned}$ & 0.81 & 1.24 & 1.2 & $\mathrm{PCL}=0.7598 \mathrm{TL}-0.1225$ & 0.75 \\
\hline
\end{tabular}

head sharks, Sphyrna mokarran (both males). The blacknose shark had the highest relative abundance between the months of May and September, with a peak in May, the same month in which the tiger shark was most caught (Figure 2). The other species were caught in low numbers enabling any assessment of seasonal variation in abundance.

Total length (TL) of the 20 tiger sharks ranged from 87.0 to $191.0 \mathrm{~cm}$, with a modal length between 70.0 and $140.0 \mathrm{~cm}$, except for 1 specimen of $346.0 \mathrm{~cm}$ (Figure 3). Total length of the bull sharks ( 2 males and 4 females) ranged from 186.0 to $250.0 \mathrm{~cm}$, with 4 of the 6 specimens measuring between 200.0 and $230.0 \mathrm{~cm}$ TL. Among the 3 blacktip sharks, 2 were juveniles ( 1 female and 1 male; 65.0 and $100.0 \mathrm{~cm}$, respectively), with the third specimen (female) measuring $190.0 \mathrm{~cm}$. The 2 hammerhead sharks (both males) measured 222.0 and $346.0 \mathrm{~cm}$ (Figure 3). The 3 shark species most caught, the blacknose, the tiger and the bull, had higher catch rates at Boa Viagem beach than at Paiva beach. The blacktip and hammerhead sharks occurred exclusively at Boa Viagem Beach (Figure 4).
Among the 86 blacknose sharks analyzed, 38 were females $(44.2 \%)$ and 48 were males $(55.8 \%)$. Females ranged from 39.0 to $164.0 \mathrm{~cm}$ TL, with $\mathrm{EW}$ ranging from 1.84 to $12.38 \mathrm{~kg}$. Males ranged from 50.0 to $180.0 \mathrm{~cm}$ TL, with eviscerated weight between 298.0 and $8,140 \mathrm{~g}$. The frequency distributions of male and female lengths were generally similar, with both genders presenting a modal length in the 100.0 to $120.0 \mathrm{~cm}$ TL class (Figure 5).

There were no statistically significant differences in the correlations between weight and total length, fork length and interdorsal length of males and females (ANCOVA $\mathrm{p}<0.05$ ) (Table 1). Thus, equations were generated for the species, regardless of sex. Among the 38 females analysed, 4 were juveniles $(10.5 \%), 12$ were maturing $(31.3 \%), 2$ were pre-ovulatory $(5.3 \%)$ and 20 were pregnant $(52.6 \%)$, with embryos ranging from 6.4 to $63.5 \mathrm{~cm}$ TL (Table 2).

Monthly distribution of mean embryo length for each pregnant female showed lower values in June, July and August. Embryos larger than $40.0 \mathrm{~cm}$ TL were only observed from November to January (Figure 6). Among the total of 83 embryos, sexing was possible for 


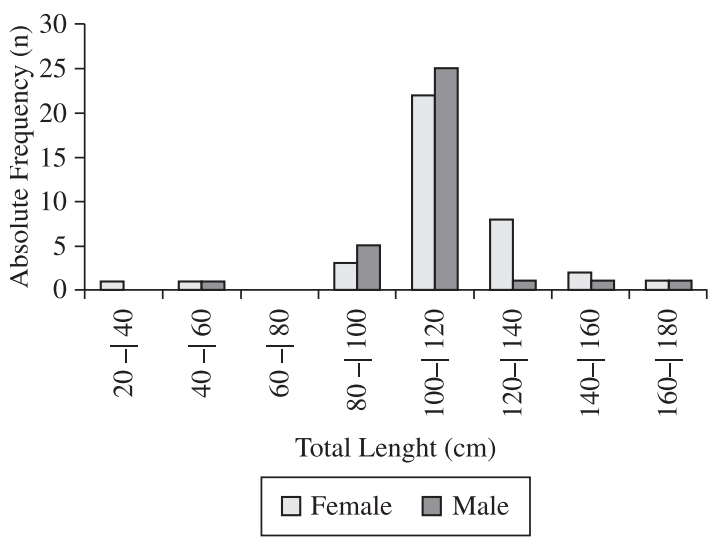

Figure 5. Frequency distribution of total length of male and female blacknose sharks caught by the Sinuelo research vessel along the coast of Pernambuco.

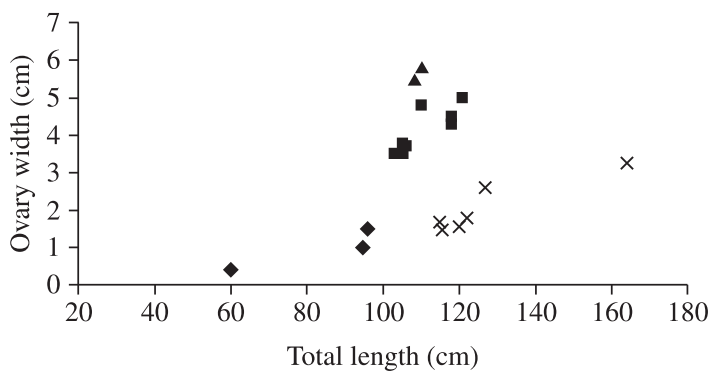

- Juvenile $\backsim$ Maturing $\Delta$ Pre-ovulatory $\times$ Pregnant

Figure 7. Correlation between total length and ovary width in female blacknose sharks caught by the Sinuelo research vessel along the coast of Pernambuco.

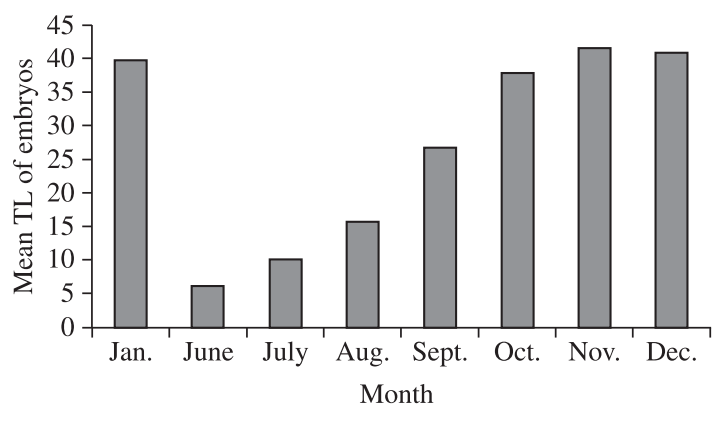

Figure 6. Monthly distribution of mean total length of blacknose shark embryos per female caught by the Sinuelo research vessel along the coast of Pernambuco.

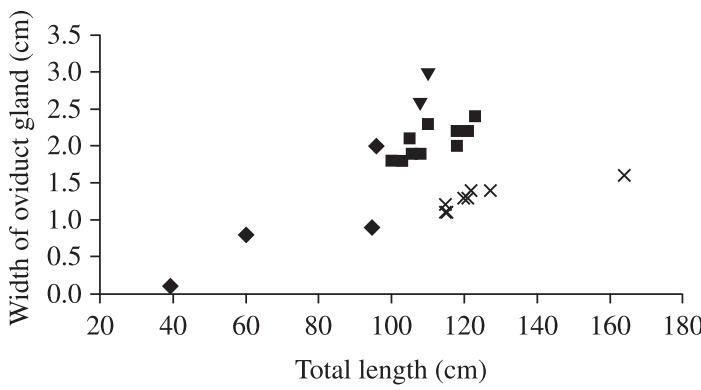

- Juvenile - Maturing $\nabla$ Pre-ovulatory $\times$ Pregnant

Figure 8. Correlation between total length and width of oviduct gland in female blacknose sharks caught by the Sinuelo research vessel along the coast of Pernambuco.

Table 2. General characteristics of maturation stages of female blacknose sharks caught by the Sinuelo research vessel off the coast of Pernambuco.

\begin{tabular}{lcccc}
\hline & Juvenile & Maturing & Pre-ovulatory & Pregnant \\
\hline Oviduct gland width $(\mathrm{cm})$ & $0.1-2.0$ & $1.8-2.4$ & $2.6-3.0$ & $1.0-1.6$ \\
Oviduct gland weight $(\mathrm{g})$ & $0.9-2.0$ & $2.8-5.8$ & $6.9-8.5$ & $1.2-2.6$ \\
Uterus width $(\mathrm{cm})$ & $0.1-1.2$ & $1.5-3.0$ & $4.5-4.8$ & $4.6-16.0$ \\
Ovary width $(\mathrm{cm})$ & $0.4-1.5$ & $3.5-5.0$ & $5.5-5.8$ & $1.2-3.3$ \\
Ovary weight $(\mathrm{g})$ & $0.7-8.0$ & $14.0-42.0$ & $55.0-62.0$ & $1.2-14.5$ \\
Diameter of largest ovarian follicle $(\mathrm{cm})$ & $0.1-1.5$ & $1.0-2.0$ & $2.5-3.0$ & $0.7-1.0$ \\
TL $(\mathrm{cm})$ & $39.0-96.0$ & $103.0-123.0$ & $108.0-110.0$ & $105.0-164.0$ \\
$\mathrm{~N}$ & 4 & 12 & 2 & 20 \\
$\%$ & 10.5 & 31.6 & 5.3 & 52.6 \\
\hline
\end{tabular}

75 (38 males and 37 females), with a sex ratio of 1 male to 0.9 females. Ovarian fecundity ranged from 5 to 10 , with a mean of 7.4 follicles per female. Uterine fecundity ranged from 1 to 3 , with a mean of 2.3 embryos for the right uterus and 2.4 for the left uterus.

The concomitant increase in ovary width (Figure 7) and oviducal gland width (Figure 8), associated to the size of the smaller pregnant females, indicates that first maturity for females occurs at around $105.0 \mathrm{~cm}$ TL. The correlation between total length and diameter of the largest vitellogenic follicle per sexual stage suggests that ovulation occurs when the follicles reaches a diameter between 2.5 and $3.0 \mathrm{~cm}$ (Figure 9).

Among the 48 males analysed six (12.5\%) were juveniles and $42(87.5 \%)$ were adults (Table 3 ). The juveniles exhibited epididymis and testes little differentiated from 


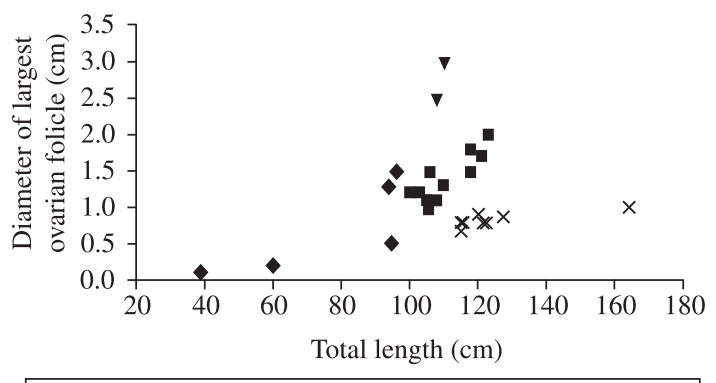

- Juvenile - Maturing $\nabla$ Pre-ovulatory $\times$ Pregnant

Figure 9. Correlation between total length and diameter of largest vitellogenic follicle in female blacknose sharks caught by the Sinuelo research vessel along the coast of Pernambuco..

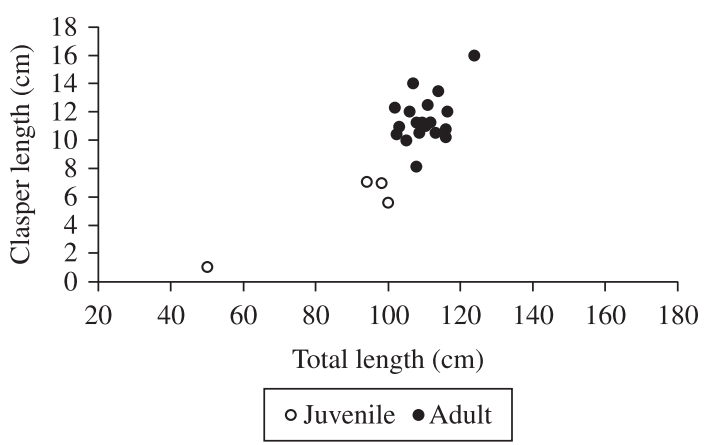

Figure 10. Correlation between total length and clasper length in male blacknose sharks caught by the Sinuelo research vessel along the coast of Pernambuco.

Table 3. General characteristics of maturation stages of male blacknose sharks caught by the Sinuelo research vessel off the coast of Pernambuco.

\begin{tabular}{lcc}
\hline \multicolumn{1}{c}{ Parameters } & Juvenile & Adult \\
\hline Testicle weight $(\mathrm{g})$ & $4.5-8.0$ & $8.0-155.0$ \\
Testicle length $(\mathrm{cm})$ & $10.0-11.5$ & $7.9-15.5$ \\
Testicle width $(\mathrm{cm})$ & $0.3-2.0$ & $0.9-2.8$ \\
Ampoule width of deferent duct $(\mathrm{cm})$ & $0.3-0.5$ & $0.5-1.6$ \\
Epididymis width $(\mathrm{cm})$ & $0.1-1.3$ & $1.0-2.3$ \\
Clasper length $(\mathrm{cm})$ & $1.0-10.5$ & $8.0-16.0$ \\
TL $(\mathrm{cm})$ & $50.0-102.5$ & $102.0-180.0$ \\
$\mathrm{n}$ & 6 & 42 \\
$\%$ & 12.5 & 87.5 \\
\hline
\end{tabular}

the epigonal organ and ampullae of the ductus deferens with a diameter of less than $0.5 \mathrm{~cm}$. Adult males had calcified claspers measuring from 8.0 to $16.0 \mathrm{~cm}$ and, unlike the juvenile specimens, had a developed epididymis and dilated ampullae of the ductus deferens, with widths ranging from 0.5 to $1.6 \mathrm{~cm}$. Males with calcified claspers were observed starting at $102.0 \mathrm{~cm}$ TL, indicating the sexual maturity probably occurs as a similar size as in females - around $105 \mathrm{~cm}$ TL (Figure 10). Table 4 displays the general characteristics of the maturation stages of the other species analysed.

Among the stomachs contents of the 86 blacknose sharks analysed, only 19 (22.1\%) had contents (Table 5). Teleosts were the most frequent item $(50.0 \%)$, followed by mollusks (31.8\%), and unidentified items (13.6\%). With the exception of the bait, the list of food items was made up of small specimens that did not surpass $12.0 \mathrm{~cm}$ in length, the majority of which inhabit reef environments.

The other shark species caught had nearly empty stomachs with only the presence of the bait or quite digested items such as vertebrae, eyes and scales from teleost fish and squid beaks, with the exception of 1 great hammerhead, which had two specimens of snapper fish (Lutjanidae) its stomach; and the largest tiger shark $(346.0 \mathrm{~cm} \mathrm{TL})$, which had a total of $17.2 \mathrm{~kg}$ of prey in its stomach, of which it was possible to identify a French angelfish (Pomacanthus paru), an olive sea turtle (Lepitochelys oliviacea), a porcupinefish (Diodon sp.) and squid beaks.

\section{Discussion}

The shark species caught in the present study coincide with those identified in previous surveys carried out on the continental shelf off the state of Pernambuco (Hazin et al. 2000), with the identification of potentially aggressive species recognised as being involved in shark attack incidents, such as the tiger shark and bull shark (Hazin et al., 1995). The frequency distribution of lengths indicate a relatively high abundance close to the beaches in the area of risk, of small to medium-sized tiger sharks (about $1.5 \mathrm{~m}$ ) and large bull sharks (about $2.1 \mathrm{~m}$ ). The highest incidence of tiger sharks in May perhaps indicates a seasonal tendency of the occurrence of the species in the area, which may be of considerable importance to develop future strategies aiming at avoiding shark attacks. This seasonality is reinforced by the observation that the tiger shark specimens were mostly caught in an aggregated manner, with up to 3 specimens caught on a single deployment of the line, indicating 
Table 4. General characteristics of maturation stages of male and female tiger sharks, bull sharks, blacktip sharks and great hammerhead sharks captured by the Sinuelo research vessel along the coast of Pernambuco.

\begin{tabular}{|c|c|c|c|c|c|c|}
\hline $\begin{array}{c}\text { No } \\
\text { Individuals }\end{array}$ & Sex & $\begin{array}{l}\text { Maturational } \\
\text { Stage }\end{array}$ & $\begin{array}{c}\mathrm{TL} \\
(\mathrm{cm})\end{array}$ & $\begin{array}{c}\text { Total } \\
\text { weight }(\mathrm{kg})\end{array}$ & $\begin{array}{l}\text { Reproductive } \\
\text { Apparatus }\end{array}$ & Characteristics \\
\hline \multicolumn{7}{|c|}{ Tiger shark } \\
\hline 19 & $\begin{array}{l}14 \text { males } \\
\text { and } \\
5 \text { females }\end{array}$ & juveniles & $\begin{array}{c}87.0 \\
\text { to } \\
191.0 \\
\end{array}$ & 2.20 to 21.10 & all & undeveloped \\
\hline 1 & male & adult & 320.0 & - & $\begin{array}{c}\text { clasper } \\
\text { testicles } \\
\text { epididymis }\end{array}$ & $\begin{array}{c}\text { calcified } \\
\text { developed, weighing } 272.0 \mathrm{~g} \\
\text { broadened, } 2.4 \mathrm{~cm} \text { in diameter }\end{array}$ \\
\hline \multicolumn{7}{|c|}{ Bull shark } \\
\hline 1 & female & juvenile & 190.0 & 68.0 & all & undeveloped \\
\hline 3 & females & adult & $\begin{array}{c}207.0 . \\
212.0 \\
\text { and } \\
250.0\end{array}$ & $\begin{array}{l}73.78 .115 .5 \\
\text { and } 152.0\end{array}$ & ovary & 8.7 to $14.5 \mathrm{~cm}$ \\
\hline 1 & male & juvenile & 186.0 & 5.0 & $\begin{array}{l}\text { oviduct glands } \\
\text { uterus } \\
\text { all } \\
\end{array}$ & $\begin{array}{c}\text { delineated, } 4.5 \text { to } 7.5 \mathrm{~cm} \\
\text { slightly broadened } \\
\text { undeveloped }\end{array}$ \\
\hline 1 & male & adult & 215.0 & 74.2 & $\begin{array}{c}\text { clasper } \\
\text { testicles } \\
\text { epididymis }\end{array}$ & $\begin{array}{c}\text { calcified } \\
\text { developed, weighing } 67.5 \mathrm{~g} \\
\text { broadened, } 3.4 \mathrm{~cm} \text { in diameter }\end{array}$ \\
\hline \multicolumn{7}{|c|}{ Blacktip shark } \\
\hline 1 & female & juvenile & 65.0 & 2.12 & all & undeveloped \\
\hline \multirow[t]{2}{*}{1} & female & $\begin{array}{l}\text { beginning of } \\
\text { gestation }\end{array}$ & 190.0 & 57.0 & ovary & $6.3 \mathrm{~cm}$ in width \\
\hline & & & & & $\begin{array}{l}\text { diameter of } \\
\text { largest ovarian } \\
\text { follicle }\end{array}$ & $2.0 \mathrm{~cm}$ in diameter \\
\hline \multirow[t]{3}{*}{1} & male & $\begin{array}{l}\text { beginning of } \\
\text { maturity }\end{array}$ & 100.0 & 6.86 & $\begin{array}{l}\text { uterus } \\
\text { clasper }\end{array}$ & $\begin{array}{c}\text { presence of eggs in interior } \\
\text { semi-calcified, } 6.0 \mathrm{~cm} \text { in } \\
\text { length }\end{array}$ \\
\hline & & & & & testicles & $\begin{array}{l}\text { slightly differentiated from the } \\
\text { epigonal organ }\end{array}$ \\
\hline & & & & & epididymis & under-developed \\
\hline \multicolumn{7}{|c|}{ Hammerhead shark } \\
\hline \multirow[t]{3}{*}{1} & male & $\begin{array}{l}\text { beginning of } \\
\text { maturity }\end{array}$ & 222.0 & - & clasper & $\begin{array}{l}\text { semi-calcified, } 6.0 \mathrm{~cm} \text { in } \\
\text { length }\end{array}$ \\
\hline & & & & & testicles & $\begin{array}{l}\text { slightly differentiated from the } \\
\text { epigonal organ }\end{array}$ \\
\hline & & & & & epididymis & under-developed \\
\hline \multirow[t]{2}{*}{1} & male & adult & 346.0 & - & $\begin{array}{l}\text { clasper } \\
\text { testicles }\end{array}$ & $\begin{array}{c}\text { calcified, } 23.5 \mathrm{~cm} \text { in length } \\
\text { developed, } 44.5 \mathrm{in} \text { width, } \\
\text { weighing } 373.0 \mathrm{~g}\end{array}$ \\
\hline & & & & & epididymis & broadened, $4.0 \mathrm{~cm}$ in diameter \\
\hline
\end{tabular}

possible group migration. Bull sharks, on the other hand, were always caught in an isolated fashion.

All the species had higher catch rates in the Boa Viagem/Piedade area than in the Paiva area. This may be related to the behaviour of the species with regard to abiotic environmental factors, such as salin- ity, submarine topography and water transparency. Besides, the greater water turbidity at Paiva Beach, as a result of its location closer to the mouth of the Jaboatão River, may affect the visibility of the bait, thereby reducing the fishing power of the fishing gears. 
Table 5. Food items found in the stomach of blacknose sharks caught by the Sinuelo research vessel along the coast of Pernambuco. $\mathrm{N}=$ number of food items; FO = frequency of occurrence. Total stomachs analyzed - 86; Stomachs with contents - 19; Empty stomachs - 67 .

\begin{tabular}{llcrrr}
\hline \multicolumn{1}{c}{ Food Items } & N & N(\%) & FO & FO(\%) \\
\hline \multirow{2}{*}{ Fish } & Teleosts (unidentified) & 8 & 36.4 & 8 & 42.1 \\
& Cephalopholis fulva & 1 & 4.5 & 1 & 5.3 \\
& Stegastes fuscus & 1 & 4.5 & 1 & 5.3 \\
\multirow{3}{*}{ Mollusks } & Muraenidae & 1 & 4.5 & 1 & 5.3 \\
& Gastropod & 1 & 4.5 & 1 & 5.3 \\
& Loliginidae & 1 & 4.5 & 1 & 5.3 \\
Bait & Octopus vulgaris & 5 & 22.7 & 5 & 26.3 \\
Unidentified & Escolar & 1 & 4.5 & 1 & 5.3 \\
Total & & 3 & 13.6 & 3 & 15.8 \\
\hline
\end{tabular}

It is likely that the greater incidence of the blacknose shark between May and September stems from migratory movements associated to the reproductive cycle of the species. The size at first sexual maturity found for females (around $105.0 \mathrm{~cm} \mathrm{TL}$ ) is smaller than that described by Branstetter (1981; $113.0 \mathrm{~cm}$ TL), but larger than $96.4 \mathrm{~cm}$ described by Driggers et al. (2004). The size at first maturity for males (here estimated at around $105.0 \mathrm{~cm}$ ) was slightly smaller than that described by Schwartz (1984; $110.0 \mathrm{~cm}$ TL), but closer to the $104.0 \mathrm{~cm}$ described by Hazin et al. (2002)

Hazin et al. (2002) suggest that birth size for blacknose shark is approximately $45.0 \mathrm{~cm}$ TL. In the present study, 2 females were observed at term with mean embryo sizes of $50.0 \mathrm{~cm}$ and $63.2 \mathrm{~cm} \mathrm{TL}$, suggesting that the $45.0 \mathrm{~cm}$ birth size may have been underestimated. The sex proportion of the embryos $(1 \hat{\delta}: 0.9+)$ was very close to that found by Driggers et al. (2004) of 1 male to 1.1 females. Uterine fecundity in the present study ( 1 to 3 embryos per female) was lower than that found for blacknose shark (1 to 5) off the South Carolina coast (USA) (Driggers, op. cit.) and in the Gulf of Mexico (Sulikowski et al., 2007). The progressive increase in embryos TL over the months suggests a 9 month gestation period, which is similar to that described by Hazin et al. (2002) and Schwartz (1984), respectively, 8 and 9 months, and lower to values presented by Dodrill (1977) and Driggers et al. (2004), which were between 11 and 12 months (both studies were carried out off Florida, USA). This divergence may be related to different temperature gradients in the study locations; it is possible that warmer waters at latitudes closer to the equator accelerate reproductive processes (fecundity, maturation, etc.) (Taniuchi et al., 1993).

The high percentage of empty stomachs found in the present study is very common among studies carried out on sharks caught with longlines and may be explained by a likely ingestion of water and regurgitation of contents when the shark is captured in an attempt to free itself from the hook (Vaske and Rincón, 1998; Wetherbee et al., 1990). According to the scale proposed by Hureau (1970), the species studied may be considered an opportunistic predator, feeding on prey common to the environment (Menezes et al., 2003) in which it was caught. The higher frequency of teleosts among the food items found suggests that the blacknose shark has a preference for this prey, which is similar to findings on Rhizoprionodon terraenovae (Hoffmayera and Parsons, 2003). The high occurrence of reef fish species in the diet of these animals indicates their insertion in and dependence on costal reef ecosystems, which are among the most threatened environments on the planet (Furriela, 2007).

Acknowledgements - The authors are grateful to the Financing Agency for Studies and Projects - FINEP, Ministry of Science and Technology of the Brazilian Government, State Government of Pernambuco, City of Recife, and the Instituto Oceanário de Pernambuco. We also thank Teodoro Vaske D.Sc. for assistance in the identification of the stomach contents, the crew of the Research Vessel Sinuelo and its respective cruise chiefs who efficiently collected the data used, Mariana Travassos, Dráusio Veras and Humberto Hazin for the assistance on earlier drafts of this paper.

\section{References}

BRANSTETTER, S., 1981. Biological notes on the sharks of the north central Gulf of Mexico. Contrib. Marine Science, vol. 24 , no. 1 , p. 13-34.

BONFIL, R., 1994. Overview of World Elasmobranch Fisheries. In FAO Fisheries Technical Paper no. 341. Rome: FAO. 119 p.

CARNEIRO, O. and COELHO, PA., 1960. Estudo Ecológico da Barra das Jangadas. Recife: Instituto de Biologia Marítima e Oceanografia, Universidade do Recife, vol. 2, no. 1, p. 237-248.

COMPAGNO, LJV., 1984. FAO Species Catalogue. Parts 2 Sharks of the world. An annotated and ilustrated catalogue of shark species known to date. FAO Fisheries Synopsis, vol. 4, no. 125 , p. 655 . 
COUTINHO, RQ., FILHO, MFL., NETO, JBS. and SILVA, EP., 1998. Características climáticas e geomorfológicas e geotécnicas da reserva ecológica de Dois Irmãos. In: MACHADO, IC., LOPES, AV. and PÔRTO, KC. (Orgs.). Reserva ecológica de Dois Irmãos: estudo em um remanescente de Mata Atlântica em área urbana (Recife - Pernambuco - Brasil). Recife: Secretaria de Meio Ambiente - SECTMA. 2149 p.

DODRILL, JW., 1977. A hook and line survey of the sharks of Melbourne Beach, Brevard County, Florida. Melbourne, FL: Florida Institute of Technology. 304 p. [Master Thesis].

DRIGGERS, WB., OAKLEY, DA., ULRICH, G., CARLSON, JK., CULLUM, BJ. and DEAN, JM., 2004. Reproductive biology of Carcharhinus acronotus in the coastal waters of South Carolina. Journal of Fish Biology, vol. 64, no. 6, p. 1540-1551.

Empresa Brasileira de Turismo - EMBRATUR, 2006. Available from: http://www.embratur.gov.br. Access in: 9 May 2006.

FURRIELA, RB., 2007. Introdução à Mudança Climática Global: desafios atuais e futuros. [S.1.]: IPAM - Instituto de Pesquisa Ambiental da Amazônia. 43 p.

HAZIN, FHV., OLIVEIRA, PGV. and BROADHURST, MK., 2002. Reproduction of the blacknose (Carcharhinus acronotus) in the coastal waters off northeastern Brasil. Fishery Bulletin, vol. 100 , no. 1 , p. 143-148.

HAZIN, FHV., BURGESS, GH. and CARVALHO, FC., 2008. A shark attac outbreak off Recife, Pernambuco, Brasil: 19922006. Bulletin Marine Science, vol. 82, no. 2, p. 199-212.

HAZIN, FHV., WANDERLEY JÚNIOR, JAM. and MATTOS, SMC., 2000. Distribuição e abundância relativa de tubarões no litoral do Estado de Pernambuco, Brasil. Arquivos de Ciências do Mar, vol. 33, no. 1, p. 33-42.

HAZIN, FHV., PINHEIRO, PB. and BROADHURST, MK., 2000. Further notes on reproduction of the blue shark, Prionace glauca, and a postulated migratory pattern in the South Atlantic Ocean. Ciência e Cultura, vol. 52, no. 2, p. 114-119.

HAZIN, FHV., LESSA, RPT. and DE MATTOS, SMG., 1995. Relatório técnico-científico do Projeto de Ecologia de Tubarões no Litoral do Estado de Pernambuco. Pernambuco: Departamento de Pesca, UFRPE. 213 p.
HOFFMAYER, ER. and PARSONS, GR., 2003. Food Habits Of Three Shark Species From The Mississippi Sound In The Northern Gulf Of Mexico. South Nat, vol. 2, no. 2, p. 271-280.

HUREAU, JC., 1970. Biologie comparée de quelques poissons antarctiques. Bulletin de l'Institut Océanographique, vol. 68, no. 1391 , p. 1-244.

MENEZES, NA., BUCKUP, PA., FIGUEIREDO, JL. and MOURA, RL. (Eds.), 2003. Catálogo das espécies de peixes marinhos do Brasil. São Paulo: Museu de Zoologia da Universidade de São Paulo. v. 1, 160 p.

NORIEGA, CD., MUNIZ, K., ARAÚJO, MC., TRAVASSOS, RK. and NEUMANN-LEITÃO, S., 2005. Fluxos de nutrientes inorgânicos dissolvidos em um estuário tropical - Barra das Jangadas - PE, Brasil. Tropical Oceanography, vol. 33, no. 2, p. $129-139$

PRATT Jr., HL., 1979. Reproduction in the blue shark Prionace glauca. Fishery Bulletin, vol. 77, no. 2, p. 445-470.

SCHWARTZ, FJ., 1984. Occurrence, abundance, and biology of the blacknose shark, Carcharhinus acronotus, in North Carolina. Northeast gulf science, vol. 7, no. 1, p. 29-47.

SULIKOWSKI, JA., III DRIGGERS, WB., FORD, TS., BOONTRA, R. and CARLSON, JK., 2007. Reproductive cycle of the blacknose shark, Carcharhinus acronotus, in the Gulf of Mexico. Journal of Fish Biology, vol. 70, no. 2, p. 428-440.

TANIUCHI, T., TACHIKAWA, H., SHIMIZU, M. and NOSE, Y., 1993. Geographic variations in reproductive parameters of shortspine spurdog in the North Pacific. Nippon Suisan Gakkaishi, vol. 59, no. 1, p. 45-51.

VASKE Jr., T. and RINCÓN, JF., 1998. Stomach content of the blue shark (Prionace glauca) and anequim (Isurus oxyrinchus) from oceanic waters of southern Brasil. Revista Brasileira de Biologia $=$ Brazilian Journal of Biology, vol. 58, no. 3, p. $445-452$

WETHERBEE, BM., GRUBER, SM. and CORTÉS, E., 1990. Diet feeding habits, digestion and consumption in sharks, with special reference to the lemon shark. Negrapion brevirostris. NOAA Technical Report, NM FS, vol. 90, no. 1, p. 29-47. 